\title{
Efficacy of Allium sativum, Curcuma longa and Zingiber officinale Extract on Cancer Antigen 15-3 (CA 15-3) Levels of Breast Cancer Patients
}

\author{
Agnes Santoso $^{1}$, Dairion Gatot ${ }^{2}$, Andri Iskandar Mardia ${ }^{2}$ \\ ${ }^{1}$ Department of Internal Medicine, Universitas Sumatera Utara \\ ${ }^{2}$ Division of Hemato Oncology, Department of Internal Medicine, Universitas Sumatera Utara
}

Corresponding Author: Agnes Santoso

\begin{abstract}
Introduction: Breast cancer is the most common malignancy in women. Progressivity of breast cancer evaluated through examination of tumor markers. Serum Ca 15-3 is tumor markers used to assess the progression. Various treatments have been developed to suppress the progression, one of which the provision of plant extractions. Extracts of Allium sativum, Curcuma longa and Zingiber officinale considered useful as anti-cancer, but no research discusses the combined benefits of extracts against breast cancer, especially Ca 15 -3.

Method: Open label clinical trial study with one group pretest posttest design was conducted at USU hospital on June 28, 2021 to July 18, 2021. Population came from breast cancer survivor community in Medan, consecutive sampling technique. Samples that met inclusion and exclusion criteria were examined for Ca 15 -3 before and after administration of extract Allium sativum, Curcuma longa and Zingiber officinale with dose $500 \mathrm{mg}$ twice a day for 28 days. Data were analyzed using SPSS version 22.
\end{abstract}

Results: Of 20 breast cancer patients analyzed with mean age of 52.7 years, majority stage III A or III B breast cancer (30\%). Median CA 15-3 before administration of extracts of Allium sativum, Zingiber and Curcuma longa 12.82 (3.29-45.81) $\mathrm{g} / \mathrm{mL}$ and after administration of extracts $8.24(2.83-47.46) \mathrm{g} / \mathrm{mL}$, decrease but not statistically significant.

Conclusion: There was decrease in median CA 15-3 before and after extraction, but not statistically significant.
Keywords: Breast Cancer, CA 15-3, Allium sativum, Curcuma longa and Zingiber officinale

\section{INTRODUCTION}

Incidence and mortality of breast cancer increase every year. One of the highest mortality rates from cancer that most often affects women is breast cancer, approximately 2.1 million people suffering from breast cancer and a mortality rate of 627,000 cases. In 2018, IARC data, the average mortality from breast cancer in women was around 15\%. ${ }^{[1]}$ Data in Indonesia, breast cancer occupying $8^{\text {th }}$ ranks in Southeast Asia with an increasing incidence every year around 1.4 per 1000 population in 2013 and 1.79 per 1000 population in $2018 .{ }^{[2]}$ Mortality is higher in developing countries than in industrial countries, this difference due to late diagnostic, treatment and poor prognosis in developing countries compared to industrial countries. ${ }^{[3]}$

Breast cancer originally due to excessive proliferation of the lobular and ductal epithelium of the breast. Assessment of breast cancer progression can be assessed through serum tumor markers, namely CA $15-3$. Tumor marker CA $15-3$ was used to assess breast cancer progression and assessment of therapeutic success. The value of the tumor marker ca $15-3$ will increase as the tumor progression. Various treatments that have been applied for the management of breast cancer include 
surgery, radiotherapy, chemotherapy, hormonal therapy, nutrition and various types of plant extracts. ${ }^{[4,5]}$

Several types of plant extracts include Allium sativum, Curcuma longa and Zingiber officinale considered to have benefits as an anti-cancer. ${ }^{[6,7,8]}$ Molecular targets of watersheds for anti-cancer include modulation of enzyme metabolic activity, modulation of the immune and inflammatory systems, inhibition of angiogenesis, apoptosis induction, cell cycle regulation and antioxidant activity. ${ }^{[9,10,11]}$. However, no research about the combination of extracts Allium sativum, Curcuma longa and Zingiber officinale on the serum marker CA-15 in breast cancer patients. Therefore, the purpose of this study was to determine the combined benefits of the three extractions on serum marker CA15 in breast cancer patients.

\section{MATERIALS AND METHODS Trial Designs \& Participants}

This study was an open label clinical trial with a one group pretest posttest design with 20 samples that were analyzed. Location of this study was at USU Hospital in Medan, Indonesia and hold on June 28, 2021 - July 18, 2021. All patients from the breast cancer survivor community in Medan city, Indonesia. The inclusion criteria in this study were breast cancer survivor who has finished all the treatment of breast cancer and age $\geq 18$ years old. Exclusion criteria was pregnant women, suffering from hepatitis $\mathrm{B}$ and $\mathrm{C}$, cirrhosis, hemangiomas, receiving breast cancer therapy (radiotherapy, chemotherapy, hormonal therapy or surgery) and patients who were not willing to be research subjects.

\section{Trial Procedures}

This clinical trial was conducted for 28 days on breast cancer survivor who met the inclusion and exclusion criteria. Patients who were willing must be asked for approval an informed concern then demography data was taken by history, a physical examination was carried out in the form of measuring height and body weight. In addition, researchers searched medical records to find breast cancer diagnosis data and other diseases data. Examined laboratory test for viral markers hepatitis B and hepatitis $\mathrm{C}$ if data was not obtained from medical records. Before and after administration of extract Allium sativum, Curcuma longa and Zingiber officinale breast cancer survivors who has finished all the treatment of breast cancer was examined the laboratory test such as liver function, kidney function, albumin, and serum $\mathrm{Ca}$ 153 levels. All participants were given supplements of Allium sativum extract, Curcuma longa, and Zingiber officinale with dose $500 \mathrm{mg}$ capsules containing a mixture of Allium sativum extract $200 \mathrm{mg}$, Curcuma longa $150 \mathrm{mg}$, and Zingiber officinale $150 \mathrm{mg}$ twice a day for 4 weeks and monitoring of adherence to drinking was carried out drug. If there were disturbing side effects and something wanted to ask from the participant, the researcher had given phone number that can be contacted at any time. On day 29, the patient returned to USU hospital for laboratory tests after administration of the extract.

This research will be started if it has obtained permission to conduct research from the research supervisor, approval from the Health Research Ethics Commission of the USU Faculty of Medicine.

\section{Extraction chemical material}

The ingredients used in this study were extracts of Allium sativum, Curcuma longa, and Zingiber officinale in capsule form. Each capsule contains $200 \mathrm{mg}$ Allium sativum extract, $150 \mathrm{mg}$ Curcuma longa, and $150 \mathrm{mg}$ Zingiber officinale.

The tools used in this study include: height meter, weight scale for anthropometry data, blood lancet, blood tube, Elecsys CA15-3 reagent (CA15-3 reagent), Elecsys CA15-3 II Calset (CA15-3 Calibrator), Precicontrol tumor marker (Control CA15-3), and ELISA tool for chemical laboratory test. 


\section{Statistical Analysis}

Data were analyzed by SPSS version 22.0. Univariate analysis was carried out to assess demographics and bivariate analysis using paired $\mathrm{T}$ test or Wilcoxon test to analyse differences in numerical variables in the study group before and after administration of Allium sativum, Curcuma Longa and Zingiber officinale extracts. Differences were considered statistically significant if $\mathrm{P}<0.05$.

\section{RESULT}

This study was followed by as many as 21 participants but 1 person lost to follow-up due to side effects that disturbing of nausea after consuming the extract. The number of subjects who followed the study was 20 people. The mean age of the participants, breast cancer patients, was 52.7 years. Based on occupation, the majority was housewives around $45 \%$. The majority of the stages of breast cancer suffered were Stage IIIA or IIIB (30\%). From the immunohistochemical examination of the type of breast cancer experienced, namely Luminal B as many as 10 people $(50.0 \%)$. The results of the anthropometric examination of the average body weight of the participants was $58.7 \mathrm{~kg}$, the average height of the participants was $155.1 \mathrm{~cm}$ and the average BMI of the participants was $24.39 \mathrm{~kg} / \mathrm{mm} 2$.

Table. 1 Characteristics of Participants

\begin{tabular}{|l|l|}
\hline Characteristics & $\mathbf{N}=\mathbf{2 0}$ \\
\hline Age, (years) & $\mathbf{5 2 . 7 \pm 8 . 4 7}$ \\
\hline Occupation, n(\%) & \\
\hline Housewife & $9(45.0)$ \\
\hline Entrepreneur & $2(10,0)$ \\
\hline Government employee & $7(35.0)$ \\
\hline Health - worker & $2(10,0)$ \\
\hline Stadium, n(\%) & \\
\hline IIB & $4(20,0)$ \\
\hline IIIA & $6(30,0)$ \\
\hline IIIB & $6(30,0)$ \\
\hline IV & $4(20,0)$ \\
\hline Immunohistochemistry, n(\%) & \\
\hline Luminal A & $4(20,0)$ \\
\hline Luminal B & $10(50.0)$ \\
\hline Negative Triple & $2(10,0)$ \\
\hline HER-2 Overexpression & $4(20,0)$ \\
\hline Body weight, (kg) & $\mathbf{5 8 . 7 \pm 7 . 6 6}$ \\
\hline Height, (cm) & $\mathbf{1 5 5 . 1 \pm 4 . 2 2}$ \\
\hline BMI, (kg/mm2) & $\mathbf{2 4 . 3 9 \pm 3 . 1 7}$ \\
\hline
\end{tabular}

Characteristics

laboratory

examination before and after administration of extraction Allium sativum, Curcuma longa and Zingiber officinale has listed in table 2 . There was a statistically significant increase in the median albumin with a value of $\mathrm{p}=0.001$. Before the intervention the median value of albumin was 4.25 (3.704.50) and after intervention the median value of albumin was 4.5 (3.50-4.70). Liver function and kidney function has changed after administration of the extract but the changing was not significant that was showed in Table 2.

On examination of CA $15-3$ the median CA 15-3 before administration of extracts of Allium sativum, Zingiber and Curcuma longa was 12.82 (3.29-45.81) $\mathrm{g} / \mathrm{mL}$, median CA 15-3 after administration of extracts of Allium sativum, Zingiber and Curcuma longa was 8.24 (2.83-47.46) $\mathrm{g} / \mathrm{mL}$, there was a decrease in the median CA 15-3 but not statistically significant with $\mathrm{p}>0.05(\mathrm{p}=0.332)$.

Table 2. Characteristics Laboratory Parameters of Patients Before and After Therapy

\begin{tabular}{|c|c|c|c|}
\hline Parameter & Pre-Intervention & $\begin{array}{l}\text { Post- } \\
\text { Intervention }\end{array}$ & $\begin{array}{l}\mathbf{p} \\
\text { value }\end{array}$ \\
\hline SGOT & $\begin{array}{l}22.5 \\
(17.00-98.00)\end{array}$ & $\begin{array}{l}21.5 \\
(14.00-54.00)\end{array}$ & 0.218 \\
\hline SGPT & $\begin{array}{l}18.5 \\
(11.00-113.00)\end{array}$ & $\begin{array}{l}20.5 \\
(11.00-75.00)\end{array}$ & 0.948 \\
\hline Albumin & $4.25(3.70-4.50)$ & $4.5(3.50-4.70)$ & $0.001 *$ \\
\hline urea & $\begin{array}{l}20.15 \\
(16.40-32.40)\end{array}$ & $\begin{array}{l}20.9 \\
(15.00-29.00)\end{array}$ & 0.667 \\
\hline Creatinine & $0.65(0.49-0.99)$ & $0.66(0.45-6.00)$ & 0.343 \\
\hline CA 15-3 & $12.82(3.29-45.81)$ & $8.24(2.83-47.46)$ & 0.332 \\
\hline
\end{tabular}

Numerical data is presented in the form of mean \pm standard deviation if the data is normally distributed, presented in the form of median (minimum valuemaximum value) if the data is not normally distributed. *Wilcoxon non-parametric test.

\section{DISCUSSION}

On examination of liver function, statistically significant differences were found in the effect of Allium sativum, Zingiber and Curcuma longa extracts on median albumin $(p=0.001)$ from this study. While the effect of giving the extract on the median SGOT and SGPT gave a difference but not statistically significant $(\mathrm{p}=0.218$ and $\mathrm{p}=0.948$ respectively). The 
hepatoprotective effect of Zingiber officinale extract reported in another study was evident from a significant reduction in elevated serum levels of liver enzymes (AST, ALT) in obese diabetic rats. ${ }^{[12]}$

Albumin is known to function as a carrier for many small molecules including drugs. ALT and AST are considered as sensitive indicators of hepatocellular damage, and these values provide a quantitative indication of the degree of liver damage due to drug administration. ${ }^{[13]}$ In this study was a statistically significant increase in the median albumin with a value of $p=0.001$. Before the intervention the median value of albumin was 4.25 (3.704.50) and after intervention the median value of albumin around 4.5 (3.50-4.70). This study is similar to a previous study which Zingiber officinale extract was given to rats showing a significant increase in albumin values in the two groups given extracts of $20 \mathrm{mg} / \mathrm{kg}$ body weight $/ 48$ hours and $40 \mathrm{mg} / \mathrm{kg}$ body weight $/ 48$ hours compared to the control group. ${ }^{[14]}$

In this study renal function examination, there was a difference but not statistically significant in the administration of the extract Allium sativum, Zingiber officinale and Curcuma longa median urea $(\mathrm{p}=0.667)$ and creatinine $(\mathrm{p}=0.343)$. Previous studies in humans, did not find the effect of oral administration of Zingiber officinale extract on serum biochemical tests for renal function (BUN, creatinine). This finding showed no side effects on the kidneys. ${ }^{[15]}$

Median CA15-3 after administration of extracts of Allium sativum, Zingiber officinale and Curcuma longa decrease but not statistically significant $(\mathrm{p}=0.332)$. This study is similar from the previous studies regarding trials of combination therapy with docetaxel (100 mg/day) and curcumin in patients with advanced and metastatic breast cancer. The study found that CA15-3 levels remained constant (not significant), while CEA levels decreased significantly. This could be due to the diminished benefits of curcumin due to its poor oral bioavailability, lipophilic features, and extensive metabolism. ${ }^{[16]}$ However, the results of this study contradict a case report in Korea by Han et al. (2017) regarding the administration of a combination of Zingiber officinale and Gemcitabine-Cisplatin chemotherapy in a 46-year-old woman with recurrent breast cancer. The study found a decrease in the tumor marker CA 15-3 from $16.7 \mathrm{ng} / \mathrm{ml}$ to $13.8 \mathrm{ng} / \mathrm{mL}$ after receiving the combination therapy for 2 months. ${ }^{[17]}$ This may be due to the limited number of research samples so that they are less representative of the population of breast cancer patients. In addition, the duration of the study which is not long also causes the results of the study to be less than optimal.

Serum CA 15-3 levels in the blood are influenced by several things, including the presence of GATA binding protein-3, breast cancer subtypes and the degree of histopathology. ${ }^{[18,19]}$ Expression of GATA binding protein-3 can predict the progression of breast cancer, which a high expression shows a much better clinical and pathological picture but in this study did not examine the Expression of GATA binding protein $-3 .{ }^{[20]}$

There are some limitations to this research. The sample community has not been able to represent the population of this study due to the small number of research samples. The short duration of this study caused results that were not optimal for the participants both in terms of benefits and side effects. Another limitation of this study was that it did not use the control group as a comparison so that the results of the study could not be compared with the control group.

\section{CONCLUSION}

Median CA 15-3 before administration of Allium sativum, Zingiber officinale and Curcuma longa extracts was 12.82 (3.29-45.81) g/mL, median CA 15-3 after administration of Allium sativum, Zingiber officinale and Curcuma longa extracts was 8, $24(2.83-47.46) \mathrm{g} / \mathrm{mL}$, there 
was a decrease in the median CA 15-3 but not statistically significant.

\section{Acknowledgement: None}

\section{Conflict of Interest: None}

\section{Source of Funding: None}

\section{Ethical Approval: Approved}

\section{REFERENCES}

1. International Agency for Reasearch on Cancer 'Latest Global Cancer Data: Cancer burden rises to 18.1 million new cases and 9.6 million cancer deaths in 2018' (12 September 2018) World Health Organization. Geneva. [Accessed January $\left.17^{\text {th }} 2021\right]$

2. Kementerian Kesehatan Republik Indonesia. (2019) 'Penyakit Kanker di Indonesia Berada Pada Urutan 8 di Asia Tenggara dan Urutan 23 di Asia' Direktorat Jenderal Pencegahan dan Pengendalian Penyakit. http://p2p.kemkes.go.id/penyakit-kanker-diindonesia-berada-pada-urutan-8-di-asiatenggara-dan-urutan-23-di-asia/. Diakses Mei 2020. [Accessed January $18^{\text {th }} 2021$ ]

3. Global Burden of Cancer Study (Globocan) 'Cancer Population Fact Sheets in World 2018' (Mei 2019) International Agency for Reasearch on Cancer. World Health Organization. Geneva. [Accessed December $\left.10^{\text {th }} 2020\right]$

4. Kementerian Kesehatan Republik Indonesia Nomor HK.01.07/MENKES/414/2018 'Pedoman Nasional Pelayanan Kedokteran Tata Laksana Kanker Payudara' (26 Juli 2018) Menteri Kesehatan Republik Indonesia. Jakarta. [Accessed December $10^{\text {th } 2020]}$

5. Robert, M., Kwiatowski,F., Leheurter,M. et al.(2010 'Phase I dose escalation trial of docetaxel plus curcumin in patients with advanced and metastatic breast cancer', Cancer Biology \& Therapy .9(1), pp : 8 14. doi : doi.org/10.4161/cbt.9.1.10392 [Accessed June 01 ${ }^{\text {st }}$ 2010]

6. Tan, B. L. and Norhaizan, M. E. (2019) 'Curcumin combination chemotherapy: The implication and efficacy in cancer', Molecules, 24(14), pp. 1-21. doi: 10.3390/molecules24142527. [Accessed January $10^{\text {th }} 2021$ ]
7. Tsubura, A., Lai, Y. C., Kuwata, M., Uehara, N. and Yoshizawa, K. (2012) 'Anticancer Effects of Garlic and Garlicderived Compounds for Breast Cancer Control', Anti-Cancer Agents in Medicinal Chemistry, 11(3), pp. 249-253. doi: 10.2174/187152011795347441. [Accessed December $13^{\text {th }} 2020$ ]

8. Mukkavilli, R., Yang, C., Tanwar, R. S., Saxena, R., Gundala, S. R., Zhang, Y. et al. (2018) 'Pharmacokinetic-pharmacodynamic correlations in the development of ginger extract as an anticancer agent', Scientific Reports. Springer US, 8(1), pp. 2-11. doi: 10.1038/s41598-018-21125-2. [Accessed December $18^{\text {th }} 2020$ ]

9. Pandrangi, A. (2015) 'Cancer Chemoprevention by Garlic - A Review', Hereditary Genetics, 04(02). doi: 10.4172/2161-1041.1000147. . [Accessed January $\left.15^{\text {th }} 2021\right]$

10. Masoudi, M. and Rahimi, R. (2017) 'Allium Sativum: A Review of Ethnopharmacology , Phytochemistry, and anti- breast cancer activity', Der Pharmacia Lettre, 9 (5), pp. 42-54. [Accessed January $13^{\text {th }} 2021$ ]

11. Moutia, M., Habti, N. and Badou, A. (2018) 'In Vitro and In Vivo Immunomodulator Activities of Allium sativum L.', Evidencebased Complementary and Alternative Medicine, 2018.2 doi: 10.1155/2018/4984659. [Accessed January $\left.24^{\text {th }} 2021\right]$

12. Ismail, N. (2014). Protective Effects of Aqueous Extracts of Cinnamon and Ginger Herbs Against Obesity and Diabetes in Obese Diabetic Rat. World Journal of Dairy \& Food Sciences, [online] 9(2), pp.145153. Available at: http://www.idosi.org/wjdfs/wjdfs9(2)14/9.p df [Accessed August $9^{\text {th }}$ 2021].

13. Aravind, S.R. and Krishnan, L.K. (2016). Curcumin-albumin conjugates as an effective anti-cancer agent with immunomodulatory properties. International Immunopharmacology, 34, pp.78-85. [Accessed March $28^{\text {th }}$ 2021]

14. Modaresi M., M. Mesri Pour and D. Zohrabi, "The effect of Ginger (Zingiber officinale) on blood chemical parameter in mice," 2010 2nd International Conference on Chemical, Biological and Environmental Engineering, 2010, pp. 86-89, doi: 10.1109/ICBEE.2010.5649429. [Accessed August 6th 2021] 
15. Bilto, Y. and Alabdallat, N. (2015). Ex vivo and In vivo Antioxidant Related Effects of Zingiber officinale Roscoe (Ginger) Extracts in Humans. European Journal of Medicinal Plants, 7(2), pp.99-108. [Accessed January $23^{\text {rd }} 2021$ ]

16. Bayet-Robert, M., Kwiatowski, F., Leheurteur, M., Gachon, F., Planchat, E., Abrial, C. et al. (2010) 'Phase I dose escalation trial of docetaxel plus curcumin in patients with advanced and metastatic breast cancer', Cancer Biology and Therapy, 9(1). doi: 10.4161/cbt.9.1.10392. [Accessed December $18^{\text {th }} 2020$ ]

17. Han, G., Lee, A-ram., Jung, J., Seong, S. and Kim, S. (2017). A Case Study of a Patient with Breast Cancer Treated with a Combination of Traditional Korean Medicine and Chemotherapy. The Journal of Internal Korean Medicine, 38(5), pp.820827. [Accessed January $20^{\text {th }} 2021$ ]

18. Jing, X., Liang , H., Hao, C., Yang, X. and Cui, X. (2019) 'Overexpression of MUC1 predicts poor prognosis in patients with breast cancer', Oncology Reports, 41(2), pp.
801-810. doi: 10.3892/or.2018.6887. [Accessed December 16 ${ }^{\text {th }} 2020$ ]

19. Apostolopoulos, V., Stojanovska, L. and Gargosky, S. E. (2015) 'MUC1 (CD227): A multi-tasked molecule', Cellular and Molecular Life Sciences. Springer Basel, 72(23), pp. 4475-4500. doi: 10.1007/s00018-015-2014-z. [Accessed January $\left.12^{\text {th }} 2021\right]$

20. Guo, Y., Yu, P., Liu, Z.,Maimati, Y., Chen, C., Zhang, Y., et al. (2017) 'Prognostic and clinicopathological value of GATA binding protein 3 in breast cancer : A systematic review and meta-analysis', PLoS ONE,12(4): e0174843. doi: 10.1371/journal.pone. 0174843 [Accessed Juli $\left.28^{\text {th }} 2021\right]$

How to cite this article: Santoso A, Gatot D, Mardia AI. Efficacy of allium sativum, curcuma longa and zingiber officinale extract on cancer antigen 15-3 (CA 15-3) levels of breast cancer patients. International Journal of Research and Review. 2021; 8(10): 196-201. DOI: https://doi. org/10.52403/ijrr.20211024 